\title{
Some Aspects of Ecological and Economic Education in the Process of Studying Geography in Pedagogical University
}

\author{
E.E. Ivanovaa \\ E.I.Veselovab \\ L.R.Mukharlyamovac \\ ab Kazan Federal University, Institute of Management, Economics and Finance, Kazan, 420008, Russia \\ c Kazan Federal University, Institute of Language, 420008, Kazan, Russia
}

Doi:10.5901/mjss.2015.v6n1s3p208

\begin{abstract}
This article deals with basic issues of ecological and economic education in the process of studying geography in Pedagogical University.

Keywords: geography, interdisciplinary communication, ecology, ecological and economic education, ecologization and economization of education, economy, economic and social geography, ecological and economic issues.
\end{abstract}

At a turn of the twentieth and twenty first centuries as never before the problem of cooperation of the nature and society, that tries to find the ways how to break an economic and ecological impasse and to transfer the relations with the nature to the course of co-authorship. The intensified attention to these issues finds its reflection in education as well.

The utmost importance in the solution of issues of ecological and economic training co-educated youth is in detection of its contents, conditions for mastering fundamentals of modern sciences of the nature, society and the person.

To identify of a role of geography in ecological and economic training and education it is necessary to address to definition of geographical science in which, in particular, it is said that the geography represents "a system of the natural and social sciences studying natural and industrial geographical complexes and their components. The system of geographical sciences is united by close interrelation between the objects studied by them and a community of the final task consisting in complex research of the nature, the population and economy and in fixing the principles of cooperation between human society and the geographical environment" [3: 5].

As the researches of many scientists show, new strategy appeared in patriotic didactics, it is an economization and ecologization of school subjects of a natural and geographical cycle.

D. Zh. Markovic in his work "Globalization and ecological education" notes that creation of the new concept of ecological education assumes the need of critical judgment of a modern education system from the point of view of widely understood changes in development of civilization, including all complex of environmental issues as well.

The understanding of an education system should be transferred from pedagogical level to the level of moral responsibility. And the important place has to belong to ecological education because the mankind is faced by an issue of realizing the safe, from the ecological point of view, development [10: 21-22].

Ecological and economic education and teaching are two directions thanks to which ecological and economic competence of future geography teachers, which are ready to carry out their professional functions effectively, and in general, to life in modern society.

The ecological and economic accomplishment follows from the term ecological and economic education, it means a result of all ecological and economic education development, which includes knowledge of laws, categories, basic principles of ecology and economy, developed ecological and economic thinking existence, formation of ecological and economic skills. Concept the ecological and economic education includes two narrower concepts: ecological and economic proficiency and ecological and economic breeding which is the expected result of ecological and economic education and which can't be reached without ecologically and economically competent teacher.

Teacher's ecological and economical competence includes some components (Pic. 1). The cognitive (knowledge) component enters the information and analytical subsystem defining the directions of the analysis of information stream, selection and designing the maintenance of ecological and economic education, development of information and 
methodical ensuring of ecoeducational process. The cognitive component is the main and it includes knowledge in the field of economy and ecology, ability to solve educational ecological and economic issues, ability to use various sources for obtaining ecological and economic information.

The analysis of the main tasks, which are set by economic and ecological components, brings forth that both of them pay much attention to a human factor as a main tool of solving its issues, both of them are also interested in forming person's new, competent and rational consciousness [7: 16-22].

The motivational and valuable component of teacher's ecological and economical competence is thought of as the motivation of economic and ecological education, interests defining student's behavior in ecological and economic activity, individual structure of ecological and economic values.

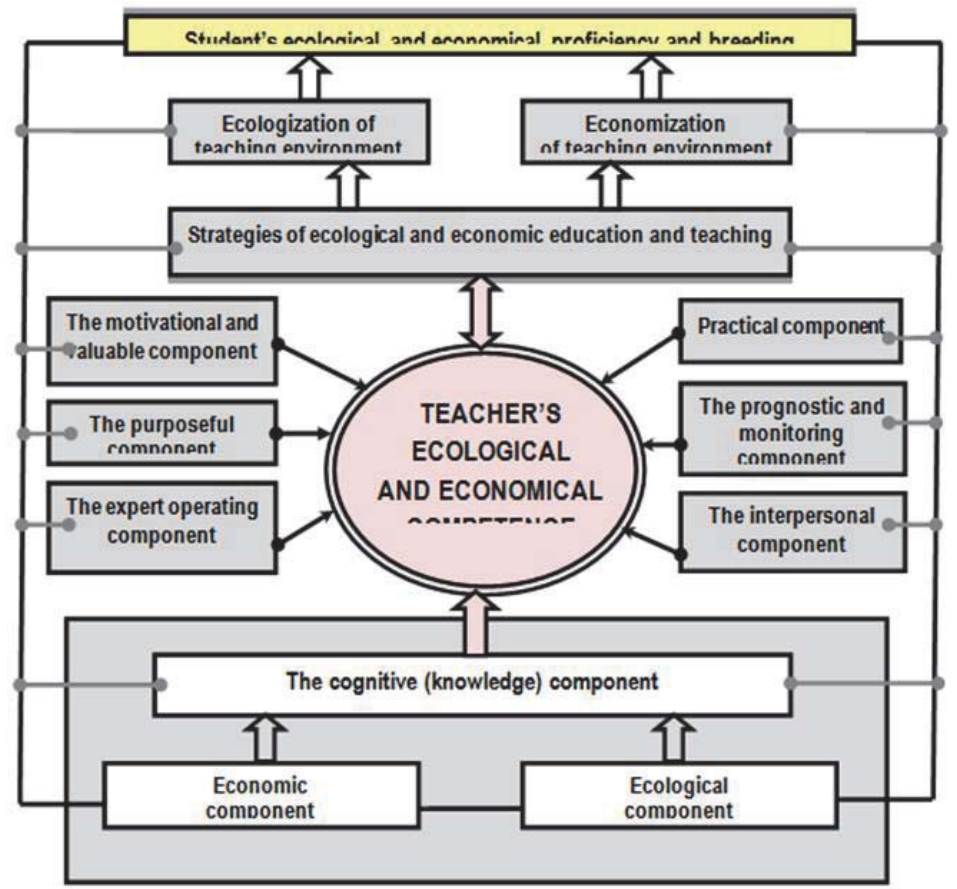

Pic.1. Model of ecological and economic education and teaching

The practical component is the ability to analyze and generalize the real economic and ecological events and situations, the ability to prove the point of view concerning economy and ecology, willingness for decision-making while being busy with educational tasks during classes and in out-of-class time.

The expert operating component sets the mechanism of organization the ecopedagogical process at the different levels, channels, devices, technologies of input of ecological and economic information in educational space.

Working in group, convincing communication, creation of relationship, and so on belong to the interpersonal component.

The prognostic and monitoring component traces the quality of economic and ecological education (the analysis and an assessment of compliance of students' economic and ecological culture level to requirements of the standard, information and methodical and material support level, the level of teaching personnel) and projects programs of students' individual development and the variable ecofocused educational models on the basis of the available resource opportunities.

In total all components there is an economic and ecological competence of the teacher which is directed on receiving the ultimate outcome - student's ecological and economic proficiency and ecological and economic breeding.

Ecological and economic proficiency is characterized by existence of the certain set level of ecological and economic knowledge, abilities, and skills of creative using the knowledge and formation of ecological and economic thinking at students. Ecological and economic breeding is a formation ecologically and economically significant qualities of the personality, such as enterprise, openness, efficiency, obligation, sense of delicacy, organization, rational thrift, diligence, feeling of the responsible owner, and others at students. 
So, ecological and economic education and teaching are basic for the modern civilized person, because they give the person a certain world outlook orientation of the personality, form the value system.

The purposes and tasks of geographical and ecological and economic education are linked together and have a lot in common. So, a methodological fundamental of ecology and economy is complexity and system approach. But, exactly, complexity forms theoretical basis of geography as well.

The geography is guided by data not only science (mathematics, chemistry, biology, physics, etc.), but also other sciences as well, such as sociology, economy, ecology, political science, psychology, jurisprudence, and others. Allowing interdisciplinary communication is the principle of development of the content of geographical education on the basis of other disciplines influence, which helps the students to understand geography better by deepening in other subjects of special issues. As a result, students form a complete image of a complex of the interconnected issues of modern mankind and the activity position of a personal responsibility for their decision.

\section{References}

Amend, A.F. Sostojanie i razvitie teorii i praktiki ekonomicheskogo vospitanija shkol'nikov / A.F.Amend. - Cheljabinsk: Izd-vo ChGPI, 2004. - PP. 71-73.

Amend, A.F. i dr. Ekologo-ekonomicheskoe obrazovanie v aspekte globalizacii / A.F.Amend, A.A.Salamatov // Vestnik Cheljabinskogo gosudarstvennogo pedagogicheskogo universiteta. - 2009. - № 6. - PP. 5-13.

Bystrakov, Y.I. i dr. Ekonomika i ekologija / Y.I.Bystrakov, A.V.Kolosov. - M.: VO "Agropromizdat", 1992. - 202 pp.

Nagimova, A.M., Safiullina, F.R. (2014). Combination of university training with employment among Kazan' students. Sotsiologicheskie Issledovaniya, (4), pp. 121-124.

Tsertseil, J.S. The way of clusters uprising and development in the region (By the example of the petrochemical cluster in the republic of Tatarstan). Mediterranean Journal of Social Sciences, Volume 5, Issue 18 SPEC. ISSUE, 2014, Pages 125-128

Safina, D., Podgornaya, A. (2014). Mobbing as an organizational phenomenon impeding implementation of changes. Mediterranean Journal of Social Sciences, 5 (18 SPEC. ISSUE), pp. 187-192

Gajsin, I.T. Preemstvennost' sistemy nepreryvnogo jekologicheskogo obrazovanija / I.T.Gajsin : Dis. dokt. ped. nauk. - Kazan', 2000. 398 pp.

Grohol'skaja, O.G. Stanovlenie i razvitie jekonomicheskogo obrazovanija v rossijskoj obshheobrazovatel'noj shkole / O.G.Grohol'skaja. Diss.dok.ped.n. - M., 1997. - P. 265.

Zakon "Ob obrazovanii v Rossijskoj Federacii" ot 29.12.2012 N 273-FZ (red. ot 21.07.2014). - Elektronnyj resurs: Rezhim dostupa: http://www.consultant.ru/document/cons doc LAW_166143/

Zverev, I.D. Prioritety jekologicheskogo obrazovanija / I.D.Žverev // Razvitie nepreryvnogo jekologicheskogo obrazovanija: Materialy 1-j Mosk. nauch. prakt. konf. po nepreryvnomu jekologicheskomu obrazovaniju. - M.: MNJePU, 1995.- PP. 16-22.

Maksakovskij, V.P. Geojekologija v ekologicheskom obrazovanii uchashhihsja / V.P.Maksakovskij // Pedagogika. - 1997 - №5. - PP. 5658.

Maksakovskij, V.P. Prepodavanie geografii v zarubezhnoj shkole / V.P.Maksakovskij. - M.: Gumanit. izd. centr VLADOS, 2001. - 368 pp.

Markovich, D.Zh. Globalizacija i ekologicheskoe obrazovanie / Dzh.Markovich // Sociologicheskie issledovanija. - 2001. - № 1. - S. 1723.

Panasyuk M.V., Pudovik E.M., Sabirova M.E. Problems of labor market of modern Russia in conditions of stable economic growth. Life Science Journal 2014; 11(6s): 487 - 489. 